\title{
Programme for Monitoring of the Greenland Ice Sheet (PROMICE): first temperature and ablation records
}

\author{
Dirk van As, Robert S. Fausto and the PROMICE project team*
}

The Greenland ice sheet is reacting to climate change. Yet, mass-budget estimates differ considerably, partly due to climatic variability and partly to uncertainties in the techniques of assessing mass change (IPCC 2007). Nevertheless, all recent estimates agree that the ice sheet is losing mass (e.g. $286 \mathrm{Gt} / \mathrm{yr}$; Velicogna 2009) at an accelerating rate (Rignot $e t$ al. 2011). On top of this, the area with a negative mass budget is expanding rapidly (Khan et al. 2010). The mass loss is attributed equally to increases in both iceberg production and melting of the ice sheet (Van den Broeke et al. 2009).

The increasing mass loss in recent years has caught public attention and given rise to concern worldwide due to its potential impact on sea level. In the light of this, the Programme for Monitoring of the Greenland Ice Sheet (PROMICE) was initiated in 2007 (Ahlstrøm \& PROMICE project team 2008), lead by the Geological Survey of Denmark and Greenland (GEUS). PROMICE undertakes surface mass-budget measurements using automatic weather stations, quantifies the mass loss by iceberg calving using remotely sensed data from satellites and airborne surveys and tracks changes in the extent of glaciers. In this paper, we focus on weather station measurements, which are crucial in calculating the energy exchange between the atmosphere and the ice sheet, and in validating model calculations of the surface mass budget. In particular, we present the observed temperatures and investigate how their high 2010 values affected ablation in southern Greenland.

\section{PROMICE automatic weather stations}

The PROMICE weather station network started with five stations in 2007 and by summer 2010 consisted of seven station pairs (Fig. 1; Table 1). Typically, one of the stations in a pair is located in the upper ablation zone near the equilibrium line and the other at a lower elevation well into the ablation zone. The weather stations are equipped with the instruments shown in Fig. 2 which undergo continuous 10 -minute measurement cycles. In summer, data are transmitted once per hour; in winter, transmissions are daily to reduce power consumption when solar power is limited.

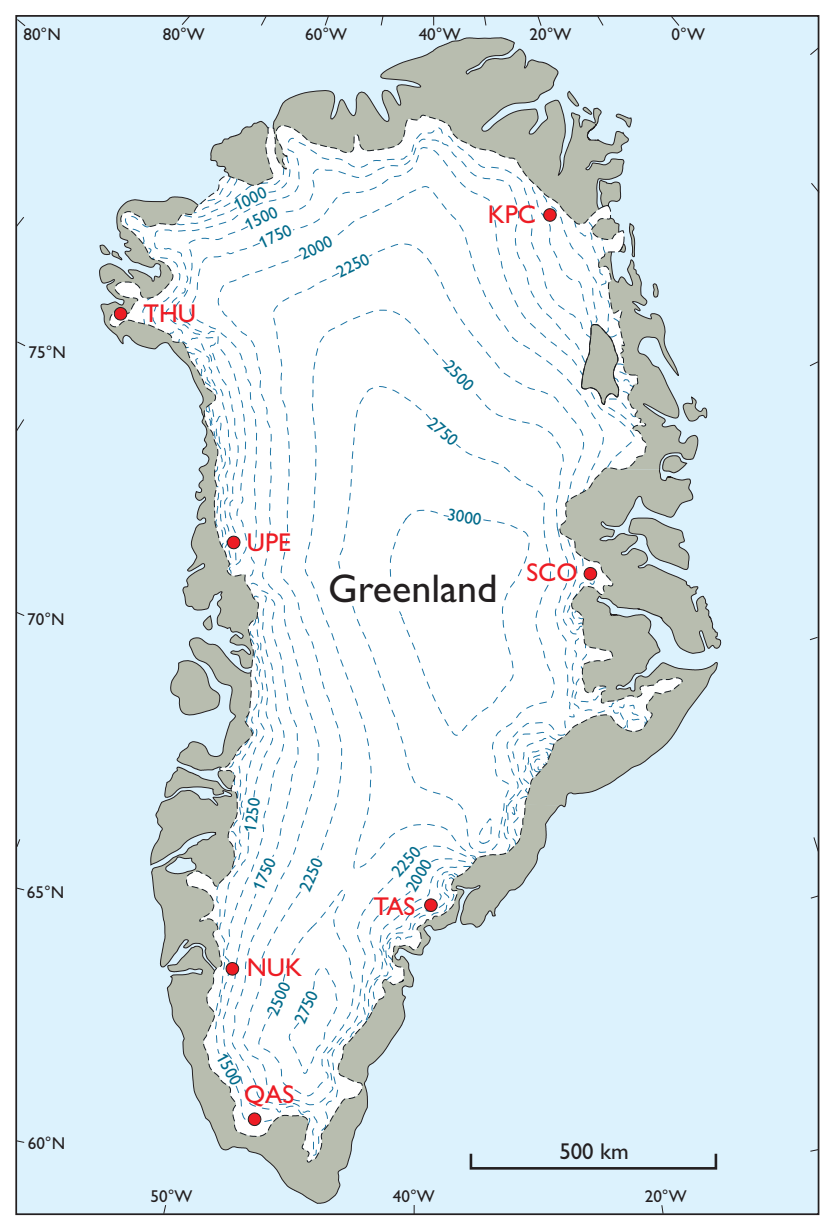

Fig. 1. Map of Greenland with the locations of the PROMICE automatic weather stations in 2010. Each dot represents a pair of stations. Station abbreviations as in Table 1. Dotted lines: elevation contours.

PROMICE weather station data can be downloaded at no charge at www.promice.dk. In spite of the stations being placed in inhospitable places where strong winds, severe cold, icing as well as melting and highly uneven terrain are common, there was a success rate of $77-86 \%$ for the period up to February 2011. Not all data have been transmitted with success, so the success rate may reach $86 \%$ when also locally

${ }^{*}$ Andreas P. Ahlstrøm, Signe B. Andersen, Morten L. Andersen, Michele Citterio, Karen Edelvang, Peter Gravesen, Horst Machguth, Faezeh M. Nick, Søren Nielsen and Anker Weidick. 
Table 1. PROMICE automatic weather station metadata (status 2010)

\begin{tabular}{|c|c|c|c|c|}
\hline $\begin{array}{l}\text { Station } \\
\text { name }\end{array}$ & $\begin{array}{c}\text { Latitude } \\
\left({ }^{\circ} \mathrm{N}\right)\end{array}$ & $\begin{array}{c}\text { Longitude } \\
\left({ }^{\circ} \mathrm{W}\right)\end{array}$ & $\begin{array}{c}\text { Elevation } \\
(\mathrm{m})\end{array}$ & Start date \\
\hline KPC_L* & $79^{\circ} 55^{\prime}$ & $24^{\circ} 05^{\prime}$ & 380 & 17 July 2008 \\
\hline $\mathrm{KPC} \cup$ & $79^{\circ} 50^{\prime}$ & $25^{\circ} 10^{\prime}$ & 870 & 17 July 2008 \\
\hline SCO_L & $72^{\circ} 14^{\prime}$ & $26^{\circ} 49^{\prime}$ & 470 & 21 July 2008 \\
\hline SCO_U & $72^{\circ} 24^{\prime}$ & $27^{\circ} 15^{\prime}$ & 1000 & 21 July 2008 \\
\hline TAS_L & $65^{\circ} 38^{\prime}$ & $38^{\circ} 54^{\prime}$ & 270 & 23 August 2007 \\
\hline TAS_U & $65^{\circ} 42^{\prime}$ & $38^{\circ} 52^{\prime}$ & 580 & 15 August 2007 \\
\hline QAS_LL & $61^{\circ} 02^{\prime}$ & $46^{\circ} 51^{\prime}$ & 310 & 24 August 2007 \\
\hline QAS_U & $61^{\circ} 11^{\prime}$ & $46^{\circ} 49^{\prime}$ & 890 & 7 August 2008 \\
\hline NUK_L & $64^{\circ} 29^{\prime}$ & $49^{\circ} 32^{\prime}$ & 560 & 20 August 2007 \\
\hline NUK_U & $64^{\circ} 30^{\prime}$ & $49^{\circ} 16^{\prime}$ & 1140 & 20 August 2007 \\
\hline UPE_L & $72^{\circ} 54^{\prime}$ & $54^{\circ} 18^{\prime}$ & 230 & 17 August 2009 \\
\hline UPE_U & $72^{\circ} 53^{\prime}$ & $53^{\circ} 32^{\prime}$ & 980 & 17 August 2009 \\
\hline THŪL & $76^{\circ} 24^{\prime}$ & $68^{\circ} 16^{\prime}$ & 570 & 9 August 2010 \\
\hline THU_U & $76^{\circ} 25^{\prime}$ & $68^{\circ} 09^{\prime}$ & 770 & 9 August 2010 \\
\hline
\end{tabular}

*L: Lower station, U: upper station.

stored data have been collected. Strikingly, only few values are missing due to harsh climatic conditions such as wind damage. A prime cause of data gaps is data logger malfunction.

\section{Temperatures over the ice sheet}

In Fig. 3 we show the monthly mean near-surface air temperatures at those PROMICE stations for which data cover at least half a month. A clear annual cycle is present in the temperature records of all weather stations, and we see that the amplitude of the annual signal increases with latitude. This is explained by the fact that during summer the solar radiation increases with latitude due to the midnight sun, while the opposite is true during winter when central and northern Greenland experiences polar night. During the 'warm' season the presence of a melting ice surface at the stations does not allow near-surface temperatures to increase well above freezing. In southern Greenland, where day-time, free atmospheric temperatures can exceed $20^{\circ} \mathrm{C}$ during summer, the melting ice surface dampens the amplitude of the temperature cycle by about $10^{\circ} \mathrm{C}$. The smallest amplitude and highest winter temperatures occur at the Tasiilaq stations (TAS_L and TAS_U), and the lower Qassimiut station (QAS_L; Fig. 1; Table 1). These stations are located at lower elevations close to the ice-sheet margin, and are exposed to the relatively warm wintertime atmospheric conditions of the Atlantic Ocean. The largest amplitude in the temperature cycle is seen at the upper Kronprins Christian Land station (KPC_U), where melting occurs in summer, but where mean temperatures drop below $-30^{\circ} \mathrm{C}$ in winter. The lowest daily mean temperature recorded at this station was $-40.6^{\circ} \mathrm{C}$ on 9 January 2010. Mid summer (July) monthly mean tem- peratures are above freezing at all stations, but never exceed $6^{\circ} \mathrm{C}$.

Temperatures in Greenland have been rising since the 1980 s, prior to which there was almost half a century of cooling (Box 2002). Still, 2010 was exceptionally warm over large parts of Greenland. It was the warmest year in Greenland on record at most of the land-based weather stations operated by the Danish Meteorological Institute. The only exception was seen in the north-east. Individual months and seasons showed record setting temperatures, with the longest instrument records in Greenland dating back to the 1870s (John Cappelen, personal communication, 2011). The PROMICE weather station network was not fully established until 2010 and thus comparison with previous years is limited. However, for our westerly and southerly stations we can confirm that the monthly mean temperatures in 2010 were mostly higher than those of previous years (Fig. 3).

\section{Record-setting 2010 in southern Greenland}

The longest running GEUS measurement series on ice started in 2001 on the Qassimiut lobe in southern Greenland. This locality was incorporated in the PROMICE network by establishing station QAS_L in 2007. The nearly 10 years

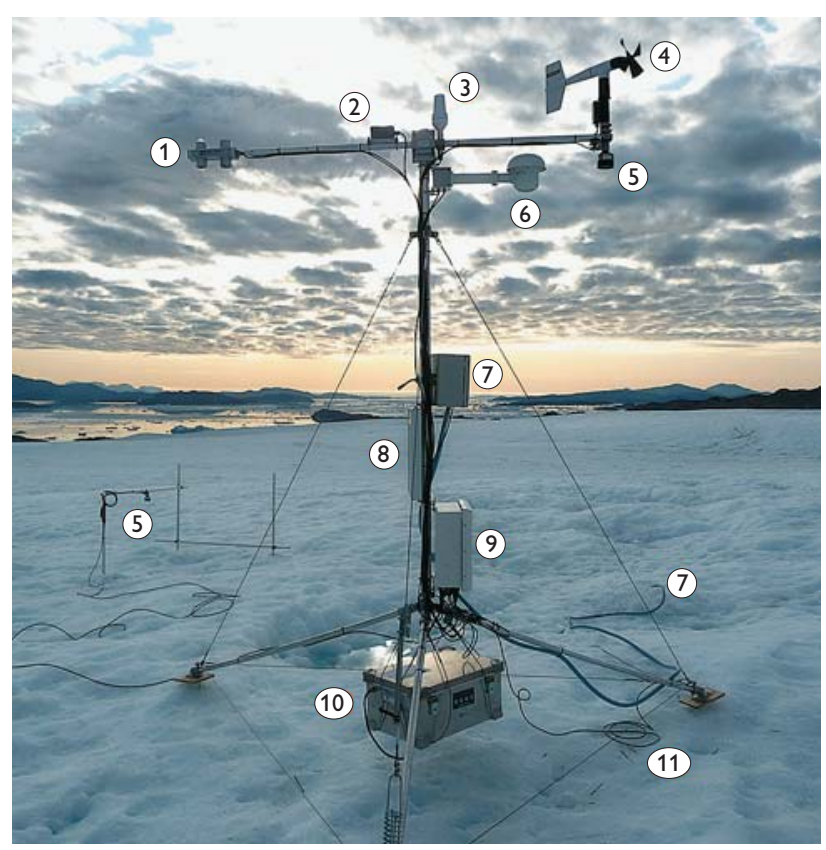

Fig. 2. PROMICE automatic weather station UPE_L photographed on 17 August 2009. 1: radiometer. 2: inclinometer. 3: satellite antenna. 4: anemometer. 5: sonic height rangers. 6: thermometer and hygrometer. 7: pressure transducer. 8: solar panel. 9: data logger, barometer and GPS. 10: battery box with $4 \times 28$ Ah batteries. 11: 8-level thermistor string. 


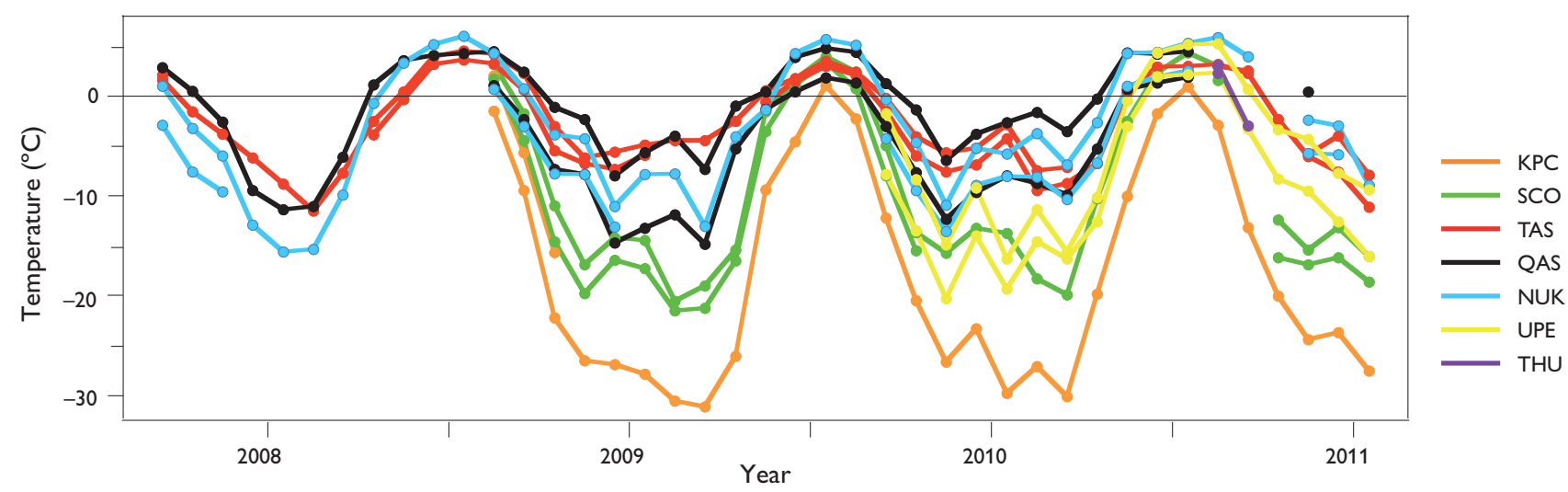

Fig. 3. Monthly mean temperatures measured at seven weather station pairs. The upper stations of each pair record the lower temperatures, and vice versa. For locations see Fig. 1.

of data from this locality provide an opportunity to put 2010 into a longer temporal perspective and assess how extraordinary 2010 was at this place. Figure $4 \mathrm{~A}$ shows all available monthly mean temperatures measured at the QAS_L site. The Qaqortoq temperature record from $56 \mathrm{~km}$ southeast of QAS_L are included to help interpret the months in 2010 with data gaps due to logger failure (values are reduced by $3^{\circ} \mathrm{C}$ to facilitate comparison).

The climate at QAS_L is mild in terms of temperature compared to most other regions on the ice sheet (Fig. 3). The lowest winter values do not drop much below $-10^{\circ} \mathrm{C}$; typical monthly mean winter temperatures during the past decade were in the -10 to $-3^{\circ} \mathrm{C}$ range. Summer (June-August) temperatures are predictable in that their mean value is within $2^{\circ} \mathrm{C}$ of all other years. The presence of ice limits the near-surface air temperature to about $5^{\circ} \mathrm{C}$ even during warm summers such as 2003 . We therefore assume that the

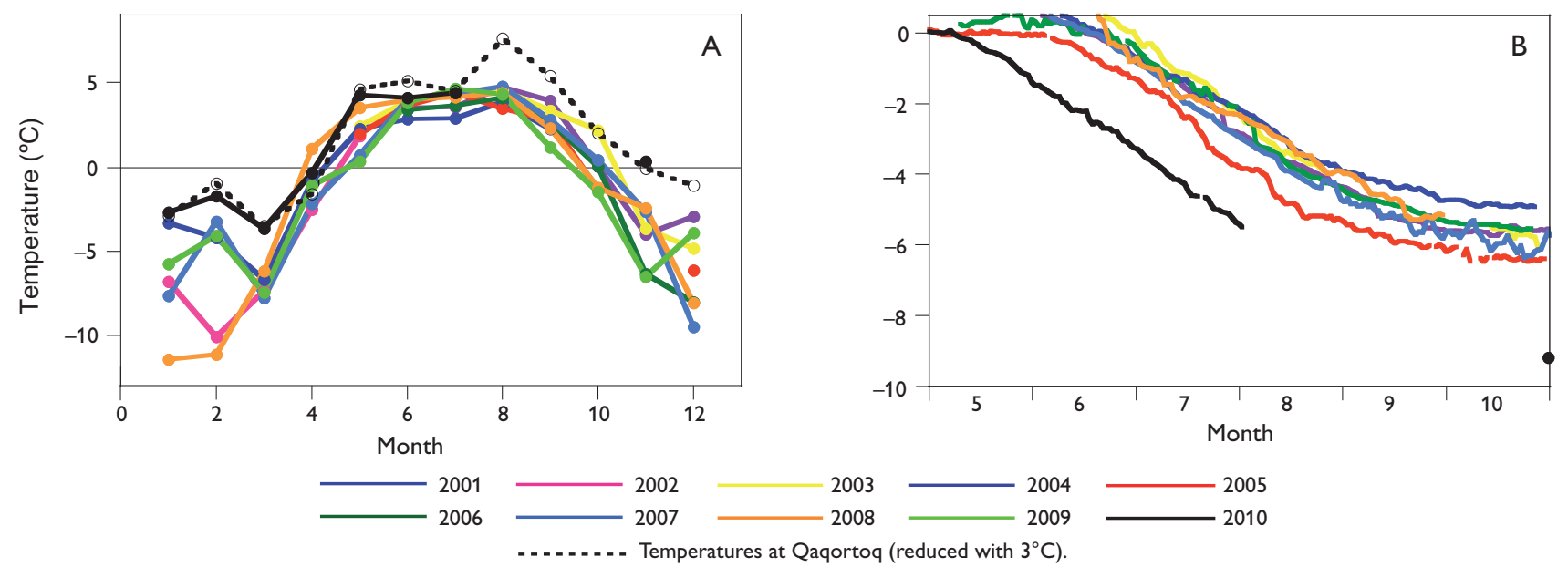

August 2010 temperature did not greatly exceed this value, even though the Qaqortoq value for this month is the highest ever recorded value $\left(10.6^{\circ} \mathrm{C}\right)$. In our records (supported by Qaqortoq data), we see that 2010 had the highest on-ice mean temperatures for all months of the year compared to earlier values, with the exception of April (warmer in 2008), July (warmer in 2003, 2005 and 2009) and October (warmer in 2003). This is in full agreement with the values from Qaqortoq, which show above-decade average temperatures for all months except July. The most extreme values (in order of excess) were November, May, August, December and September, which exceeded the two standard deviation ranges for the 2000-2009 averages. Qaqortoq was on average an astonishing $2.0^{\circ} \mathrm{C}$ warmer in 2010 than in the second (2003) and third (2005) warmest years on record, 4.5 standard deviations above the 2000-2009 average (which is the warmest decade on record).

Fig. 4. A: Monthly mean temperatures and B: cumulative net ablation at lower Qassimiut station (QAS_L). The ablation measurements are by pressure transducer; supported and validated by sonic ranger where available. The black dot in B shows the total ablation by November 2010 . Variability in the pressure transducer output is caused by atmospheric pressure. 
Even though QAS_L summer temperatures are dampened by the ice surface and on average do not exceed $5^{\circ} \mathrm{C}$, this does not imply that melt rates are similar between years. The energy consumed by the ice surface to cool the near-surface atmosphere (sensible heat flux) will be larger during warmer periods, as will the down-welling longwave radiation, thus enhancing melting. However, there is only a relatively small amount of year-to-year variability in melt rates (given the slopes of the ablation curves from the pressure transducer in Fig. 4B) since solar radiation is the main contributor to melt energy (Van As et al. 2009). More important to net ablation is the length of the ice-melt season, which largely depends on the duration of the period with positive temperatures and the amount of snow accumulation in the preceding winter. For instance, even though the melt rate in 2003 was above average due to high temperatures, the total ablation was near average because of the time it took to melt the relatively large amount of snow that had accumulated during the preceding winter. The year 2005 had lower summer temperatures, but a larger ablation total as there was very little snow accumulation the previous winter. The net ice ablation observations for the period 2001-2009 range from $5 \mathrm{~m}$ to $6.5 \mathrm{~m}$ of ice per year, which are the largest ablation totals measured anywhere on the Greenland ice sheet. For 2010 the extreme months of August and September are lacking from our data series, but spring values show that hardly any snow had accumulated in winter, and that the melt of the bare ice surface began in early May, 1-2 months earlier than in previous years. Melt rates were high in late summer and autumn, setting a new ablation record with a measured end-of-year total of about $9 \mathrm{~m}$ of ice (Fig. 4B, black dot). Similar record setting ablation is expected to have taken place in all of southern Greenland, as well as along the western margin of the Greenland ice sheet (Tedesco et al. 2011).

\section{Conclusions}

PROMICE has been successful in acquiring near-surface meteorological data over the Greenland ice sheet since 2007. Temperature measurements display distinct differences between the locations due to solar influences, elevation and regional climate. The PROMICE temperature record confirms that 2010 was an exceptionally warm year in the southern and western regions of Greenland, although a longer time series is needed to quantify the 2010 anomaly over the ice sheet. A record-setting net ablation of $9 \mathrm{~m}$ of ice in Greenland was measured on the southernmost part of the ice sheet in 2010. The enhanced down-welling longwave radiation and sensible heat flux due to the high atmospheric temperatures are not the main reason for the large ablation; low snow accumulation in the previous winter and a long melt season are.

\section{Acknowledgements}

The Programme for Monitoring of the Greenland Ice Sheet (PROMICE) is funded by the Danish Ministry of Climate and Energy, and is conducted in collaboration with the National Space Institute (DTU Space) and Asiaq (Greenland Survey). The Greenland Climate Research Centre (GCRC) co-finances the NUK stations through the FreshLink and ImGlaCo projects.

\section{References}

Ahlstrøm, A.P. \& PROMICE project team 2008: A new programme for monitoring the mass loss of the Greenland ice sheet. Geological Survey of Denmark and Greenland Bulletin 15, 61-64.

Box, J.E. 2002: Survey of Greenland instrumental temperature records: 1873-2001. International Journal of Climatology 22, 1829-1847.

IPCC 2007: Intergovernmental Panel on Climate Change (IPCC) Fourth Assessment Report (AR4), Climate Change 2007. 4 volumes. Cambridge: Cambridge University Press.

Khan, S.A., Wahr, J., Bevis, M., Velicogna, I. \& Kendrick, E. 2010: Spread of ice mass loss into northwest Greenland observed by GRACE and GPS. Geophysical Research Letters 37, L06501. Doi: 10.1029/2010GL042460.

Rignot, E., Velicogna, I., Van den Broeke, M.R., Monaghan, A. \& Lenaerts, J. 2011: Acceleration of the contribution of the Greenland and Antarctic ice sheets to sea level rise. Geophysical Research Letters 38, L05503. Doi:10.1029/2011GL046583.

Tedesco, M., Fettweis, X., Van den Broeke, M.R., Van de Wal, R.S.W., Smeets, C.J.P.P., Van de Berg, W.J., Serreze, M.C. \& Box, J.E. 2011: The role of albedo and accumulation in the 2010 melting record in Greenland. Environmental Research Letters 6, 014005. Doi: 10.1088/17489326/6/1/014005.

Van As, D., Bøggild, C.E., Nielsen, S., Ahlstrøm, A.P., Fausto, R.S., Podlech, S. \& Andersen, M.L. 2009: Climatology and ablation at the South Greenland ice sheet margin from automatic weather station observations. The Cryosphere Discussions 3, 117-158.

Van den Broeke, M., Bamber, J., Ettema, J., Rignot, E., Schrama, E., Van de Berg, W.J., Van Meijgaard, E., Velicogna, I. \& Wouters, B. 2009: Partitioning recent Greenland mass loss. Science 326, 984-986.

Velicogna, I. 2009: Increasing rates of ice mass loss from the Greenland and Antarctic ice sheets revealed by GRACE. Geophysical Research Letters 36, L19503. Doi: 10.1029/2009GL040222.

Authors' address

Geological Survey of Denmark and Greenland, Øster Voldgade 10, DK-1350 Copenhagen K, Denmark. E-mail: dva@geus.dk 